\title{
Avaliação de parâmetros químicos, microbiológicos e parasitológicos de águas de abastecimento da UNESP e residuária, no município de Jaboticabal, Estado de São Paulo
}

\author{
Analyze chemistry, microbiological and parasitological of the drinking water in \\ UNESP and wastewater from Jaboticabal - SP, Brazil
}

\author{
Antonio João Scandolera' ${ }^{1,2}$; Julio César Palhares ${ }^{3}$; Jorge de Lucas Junior ${ }^{4}$; Luiz Augusto do \\ Amaral $^{4}$; Rafael Paranhos de Mendonça ${ }^{1}$; Gilson Pereira de Oliveira ${ }^{1}$
}

\begin{abstract}
Resumo: Objetivou-se avaliar as condições da qualidade da água de abastecimento do Campus Universitário da UNESP de Jaboticabal e residuária na micro-bacia do Córrego do Jaboticabal, por meio de análises químicas, bacteriológicas e parasitológicas. Amostras foram colhidas semanalmente no período de 24/09/98 a 28/01/99 definindo-se água de abastecimento como aquela fornecida pelo poder público, proveniente de poço artesiano e água residuária, oriunda de um ponto de colheita localizado no Córrego Cerradinho a jusante da cidade. Os parâmetros analisados foram: $\mathrm{pH}$, oxigênio dissolvida (OD), nitrato, nitrito, amônia, demanda química de oxigênio (DQO) e demanda bioquímica de oxigênio (DBO), coliformes fecais, coliformes totais e ovos de helmintos apenas na água residuária. Os resultados mostraram que a água de abastecimento possuía altas concentrações de OD (6,2 a 8,9 mg/L). A DBO foi nula para todas as amostras, sendo a DQO baixa $(0,0$ a $18 \mathrm{mg} / \mathrm{L})$. As formas nitrogenadas apresentaram valores aceitáveis. A água residuária apresentou-se atóxica na maioria das colheitas, apesar das concentrações de DQO e DBO (32 a 201 $\mathrm{mg} / \mathrm{L}$ de $\mathrm{DQO}$ ) e (18 a $113 \mathrm{mg} / \mathrm{L}$ de DBO) mostrarem reduzidas. O nitrato prevaleceu em relação ao nitrito, estando a amônia presente em concentrações muito altas (0,0 a 13,4 mg/L). Quanto aos parâmetros bacteriológicos 35,3\% das amostras da água do Campus da UNESP de Jaboticabal apresentaram-se impróprias para o consumo humano. A água do córrego Cerradinho apresentou elevadas concentrações bacteriológicas e de ovos de helmintos. Conclui-se que a qualidade da água de abastecimento servida no Campus de Jaboticabal precisa ser monitorada desde sua captação até a sua distribuição, visando à identificação dos possíveis pontos de contaminação, para a tomada de ações preventivas que solucionem o problema de inconstância na sua qualidade. A água residuária, em função da elevada concentração de organismos potencialmente patogênicos, níveis tóxicos de amônia e elevada DQO e DBO, necessitam de tratamentos para ser utilizada na irrigação e na dessedentação animal.
\end{abstract}

Palavras-chave: qualidade da água, parâmetros químicos, coliformes fecais , coliformes totais, micro-bacia, córrego Jaboticabal.

\begin{abstract}
The quality conditions of the water that supplies the UNESP University campus in Jaboticabal city and its wastewater from the Jaboticabal Stream were evaluated by chemical analysis bacteriological and parasitological. Samples were collected weekly from 09/24/98 through 01/28/99, water supply provided by the Municipal Government from an artesian well source and wastewater was took from the Jaboticabal Stream at a point downstream from the town. The parameters analyzed were: water $\mathrm{pH}, \mathrm{DO}$, nitrate, nitrite, ammonia, $\mathrm{COD}$ and BOD, coliform bacillus and helminths eggs only in wastewater. The results showed with high DO concentrations $(6,2$ to $8,9 \mathrm{mg} / \mathrm{L})$ in the water supply. BOD was void for all samples, with low COD $(0,0$ to $18 \mathrm{mg} / \mathrm{L})$. Nitrogen forms showed acceptable values. Wastewater was anoxic in the majority of the samples, but COD and BOD concentrations were reduced in this kind of water ( 32 to $201 \mathrm{mg} / \mathrm{L} \mathrm{COD}$ and 18 to $113 \mathrm{mg} / \mathrm{L}$ BOD). Nitrate prevailed over nitrite, and ammonia concentrations were too high $(0,0$ to $13,4 \mathrm{mg} / \mathrm{L})$. As for the bacteriological parameters to $35,3 \%$ of the samples of the water of the Campus presented inappropriate for the human consumption. The water from the Cerradinho Stream showed high bacteriological and helminths eggs concentration. It can be concluded that the wastewater must receive treatment to be used by animals or agricola irrigation because of the potential pathogenic organism, ammonia, COD and BOD high concentrations.
\end{abstract}

Key words: quality of the water, chemical parameters, fecal coliforms, total coliforms.

\footnotetext{
${ }^{1}$ CPPAR-Centro de Pesquisas em Sanidade Animal, FCAVJ/UNESP, Campus de Jaboticabal

${ }^{2}$ Aluno de pós-graduação, FCAV/UNESP, Jaboticabal.

${ }^{3}$ Pesquisador II Embrapa Suínos e Aves.

${ }^{4}$ FCAVJ/UNESP, Campus de Jaboticabal
} 


\section{Introdução}

As águas em todo o planeta cobrem três quartos da superfície da Terra, no entanto, mais de $97 \%$ é salgada e menos de $3 \%$ é água doce. Desta última, $77 \%$ apresentam-se congelados nos círculos polares, $22 \%$ compõem-se de águas subterrâneas e a pequena fração restante encontra-se nos lagos, rios, plantas e animais (WORLD RESOURCE INSTITUTE AND INTERNATIONAL INSTITUTE FOR ENVIRONMENT AND DEVELOPMENT, 1988). Constituem-se em um recurso natural finito que, com a escassez futura, poderá limitar o crescimento da agropecuária e da indústria, colocando em risco a saúde, nutrição e desenvolvimento econômico.

Desta forma, o universo aqüífero deve ser preservado em quantidade e qualidade para que o desenvolvimento e o progresso da sociedade mundial não sejam comprometidos. Tal preservação inclui várias medidas, como: conservação de nascentes e mananciais de abastecimento, bem como dos lençóis subterrâneos; conscientização e educação das sociedades, visando ao uso racional das águas; estabelecimento de parâmetros para um desenvolvimento sustentável dos recursos hídricos; colheita de esgotos urbanos, industriais e rurais, com posterior tratamento, dentre outras.

Pela história do surgimento das cidades, pode-se constatar que nossos antepassados optaram por locais nos quais a disponibilidade de água era abundante, com facilidades para o despejo de seus esgotos. Tinha-se a visão de que os cursos d'água existiam para dois propósitos: o fornecimento de água de qualidade e meio de carreamento de materiais e substâncias indesejáveis. Atualmente esta visão é incompatível com os conceitos ambientais que norteiam nosso presente e futuro, pois os rios continuam a ser fornecedores de água, em muitos casos com baixa qualidade, mas não podem continuar sendo objeto de despejo de todo e qualquer tipo de material estranho à sua natureza.

Assim, o gerenciamento dos recursos hídricos exige grandes esforços para melhorar a eficiência dos processos de tratamentos, da conservação e dos sistemas de colheitas de águas residuárias (RENEW AMERICA, 1989).

No Brasil o número de cidades que possuem coleta de esgotos é pequeno, sendo reduzidas as localidades em que, a estes esgotos, é dado um tratamento antes de despejá-los nos rios. Vários são os motivos para estas ocorrências, enquadrando-se a falta de recursos financeiros nos municípios, falta de interesses políticos por este tipo de obra, consciência ambiental da população e a cultura que predomina em nosso país, pois pensase que água, aqui, nunca irá faltar.

A presença de compostos nitrogenados nos seus diferentes estados de oxidação é indicativo de contaminação do aqüífero e de possíveis condições higiênicosanitárias insatisfatórias. Atualmente, por estar se tornando um problema mundial, a contaminação da água por estes compostos tem recebido atenção especial. Alaburda e Nishihara (1998) verificaram que, de 607 amostras de águas de poços localizados na região metropolitana da Grande São Paulo, 15\% apresentaram teores de pelo menos uma forma de nitrogênio em desacordo com a legislação estadual. Tais achados levaram os autores a concluir que a contaminação das águas subterrâneas por compostos de nitrogênio é significativa no Estado de São Paulo, sugerindo, ainda, que seu monitoramento é de vital importância e deve ser realizado para viabilizar uma rediscussão da legislação federal que, por sua vez não estabelece limites para as concentrações de nitrogênio amoniacal, albuminóide e nitrito.

Ainda, a água normalmente é habitada por vários tipos de microrganismos que dela extraem os elementos indispensáveis à sua sobrevivência. No entanto, organismos patogênicos ocasionalmente são introduzidos nos corpos d'água, e, utilizando a água como veículo, constituem-se um perigo sanitário potencial.

A detecção de Coliformes totais em amostras de águas não é necessariamente um indicativo de contaminação fecal, pois o grupo designado como coliformes totais engloba um grande número de bactérias, entre elas a Escheríchia coli, esclusivamente de origem fecal e que dificilmente multiplica-se fora do trato intestinal, no entanto engloba também outras bactérias dos gêneros Citrobater, Eriterobacter e Klebsiella, igualmente identificadas pelas técnicas laboratoriais como coliformes totais e que são comumente encontradas no solo e nos vegetais (SOUZA e PERRONE, 2000).

Considerando-se a situação vigente, torna-se necessário o desenvolvimento de pesquisas tendo as bacias hidrográficas como unidades de estudo, localizando os pontos de poluição e diagnosticando as condições qualitativas de seus recursos hídricos. Para tanto, fazse necessário o uso de colheitas de dados relacionados à qualidade da água avaliando-se seus contaminantes (ARCHIBALD, 1994).

O município de Jaboticabal está localizado na Bacia Hidrográfica do Rio Mogi Guaçu, correspondendo à $7^{\text {a }}$ zona hidrográfica do Estado de São Paulo. Sua microbacia é denominada Córrego do Jaboticabal, sendo formada pelo Córrego Rico e Ribeirão Cerradinho. De acordo com a Secretaria do

Meio Ambiente do Estado de São Paulo (1990), as águas compreendidas entre a confluência do Córrego Rico e Ribeirão Cerradinho e a confluência com o Rio Mogi-Guaçu se enquadram na "classe 3" e as do Ribeirão Cerradinho até a confluência com o Córrego Rico, à "classe 4".

As coordenadas geográficas do município são: Latitude, $21^{\circ} 15^{\prime} 22$ "; Longitude, $48^{\circ} 18^{\prime} 58^{\prime \prime}$ W.Gr. e Altitude de $575 \mathrm{~m}$. O clima, segundo classificação de KOPPEN é "Cwa", isto é, subtropical úmido, seco no inverno e com chuvas no verão, com precipitação anual em torno de $1400 \mathrm{~mm}$ e temperatura média anual próxima a $22^{\circ} \mathrm{C}$.

A presente pesquisa objetivou avaliar as condições da qualidade da água de abastecimento fornecida pelo poder público à comunidade universitária do Campus 
da UNESP de Jaboticabal, Estado de São Paulo (SP), e daágua residuária na micro-bacia do Córrego do Jaboticabal. Para o estudo, parâmetros químicos (pH, oxigênio dissolvido (OD), formas nitrogenadas, demanda bioquímica de oxigênio (DBO) e demanda química de oxigênio (DQO), microbiológicos e parasitológicos foram avaliados.

\section{Material e Métodos \\ 2.1 Amostras de água}

As amostras de água (aproximadamente $300 \mathrm{~mL}$ ) foram colhidas semanalmente entre 08/09/1998 e 31/ 12/1998, em frascos de vidro estéreis, na área do Centro de Pesquisas em Sanidade Animal (CPPAR) e analisadas no Departamento de Engenharia Rural, Faculdade de Ciências Agrárias e Veterinárias de Jaboticabal (FCAVJ-UNESP).

A água de abastecimento sofre captação do tipo subterrânea (poço artesiano) e não recebe qualquer tratamento antes de ser fornecida a comunidade universitária, sendo utilizada tanto para o abastecimento humano como na agropecuária. As amostras foram colhidas diretamente de uma torneira.

Por sua vez, amostras da água residuária foram colhidas no Ribeirão Cerradinho, no trecho em que passa nas imediações do CPPAR, após recebimento dos afluentes da Faculdade de Ciências Agrárias e Veterinárias, margem direita, portanto, o ponto de colheita estava localizado a jusante da zona urbana.

As colheitas foram realizadas, semanalmente, no período de 24/09/98 a 28/01/99.

As amostras de água bruta (poluída), destinada a analise parasitológica, foram colhidas sempre no mesmo dia da semana e horário, procedendo-se a sucção de 190L da água do córrego, até um reservatório previamente higienizado (caixa de fibrocimento) que, após o seu enchimento, permaneceu fechado e em repouso durante 24h.

Após cuidadosa drenagem de quase toda a água, tomaram-se os últimos 2 litros em proveta, e após um período de repouso de três horas, descartaram-se $500 \mathrm{ml}$ do sobrenadante. Do volume restante, sob cuidadosa homogeneização, recolheram-se $300 \mathrm{ml}$ que foram levados para o laboratório, estocados em garrafas de vidro, fixados com formaldeído a $4 \%$ e mantidos em temperatura de $4^{\circ} \mathrm{C}$ até a análise helmintológica.

\subsection{Variáveis químicas da água}

\section{A. $\mathrm{pH}$}

$\mathrm{O} \mathrm{pH}$ de todas as amostras foi registrado por meio de um medidor portátil (Corning, modelo PS15).

\section{B. Oxigênio Dissolvido (OD)}

Este parâmetro foi determinado pelo método de Winkler, segundo Golterman et al.(1978).

\section{Formas Nitrogenadas}

As formas nitrogenadas foram determinadas pelos métodos nitrato (Cadmium Reduction Method - low range), nitrito (Diazotization Method - low range) e amônia (Salicylate Method), utilizando-se reagentes para análise de água da "HACH". Os valores foram obtidos por método colorimétrico, empregando-se espectrofotômetro modelo DR-2000 da HACH.

\section{Demanda Bioquímica de Oxigênio (DBO)}

Os valores da Demanda Bioquímica de Oxigênio (DBO) foram obtidos de acordo com a metodologia descrita na publicação American Public Health Association APHA (1992).

\section{E. Demanda Química de Oxigênio (DQO)}

Obtiveram-se os valores da demanda química de oxigênio (DQO) por método colorimétrico, empregandose espectrofotômetro modelo DR-2000 da HACH e bloco digestor para $\mathrm{DQO}$ de mesma marca. A metodologia descrita nos manuais do aparelho faz uso de digestão ácida em meio com dicromato de potássio e catalisadores, utilizando-se reta padrão registrada na memória do aparelho.

\subsection{Avaliação microbiológica}

Para as análises colimétricas (Coliformes fecais e Coliformes totais) foi empregada a técnica de tubos múltiplos (APHA, 1992).

Tais análises foram conduzidas junto ao Laboratório de Análises de alimentos de origem animal e água, do Departamento de Medicina Veterinária Preventiva e Reprodução Animal da FCAVJ/UNESP.

Das amostras de água da torneira (rede) foram feitas três diluições em meio de cultura Lauril Sulfato, usando séries de 5 tubos em cada diluição. Foram semeados $10 \mathrm{ml}$ na primeira série de 5 tubos, $1 \mathrm{ml}$ na segunda série e $0,1 \mathrm{ml}$ na terceira série.

Para a água poluída (procedente do córrego), procedeu-se previamente a uma série de diluições em água peptonada, na ordem de $10^{-1}$ até $10^{-9}$, utilizandose apenas as diluições de $10^{-4}$ até $10^{-9}$ para os estudos de colimetria. Neste caso foi utilizada uma série de três tubos para cada diluição.

Após semear as amostras em meio de cultura Lauril Sulfato, os tubos foram incubados em estufa a $35 \pm 0,5^{\circ} \mathrm{C}$, durante 48 horas, quando foram feitas as leituras. Foram considerados positivos os tubos Durham quando houve acumulação de gás no interior. O teste confirmativo foi realizado a partir dos respectivos tubos positivos no teste presuntivo, transferindo-se uma alíquota para Caldo Lactosado Bile Verde Brilhante e outra em caldo E.C..

As culturas em Caldo Lactosado Bile Verde Brilhante foram incubadas em estufa a $35 \pm 0,5^{\circ} \mathrm{C}$ durante 48 horas, enquanto as culturas em meio E.C. foram mantidas em banho-maria a $44,5^{\circ} \mathrm{C}$ durante 24 horas, quando então fez-se a leitura, observando-se a formação de gás no interior do tubo de Durham.

A quantidade de coliformes fecais, expressa como o número mais provável de coliformes por $100 \mathrm{~mL}$ (NMP) foi obtida utilizando-se tabelas em que o NMP é fornecido 
com os limites de confiança de $95 \%$. Para as amostras de água potável utilizou-se tabela que fornece o NMP para combinações de resultados positivos e negativos quando são inoculados séries de cinco tubos (HIGASKINO et al., 1998; APHA, 1992). Enquanto que, para as amostras com diluições de $10^{-4}, 10^{-5}, 10^{-6}, 10^{-7}, 10^{-8}$, $10^{-9}$ feitas em séries de 3 tubos (água poluída), foi utilizada a tabela de Hoskins (APHA, 1992).

\subsection{Avaliação qualitativa e quantitativa dos ovos de helmintos na água do córrego}

Da amostra de $300 \mathrm{ml}$ reservados para a análise parasitológica, após cuidadosa homogeneização, foi colhida uma amostra de $100 \mathrm{ml}$ para pesquisa de ovos de helmintos, particularmente daqueles pertencentes ao gênero Taenia. Para tal, adotaram-se as técnicas de Bailinger, segundo Ayres e Mara (1996), empregandose a seguinte equação para o cálculo do número de ovos por litro de água:

$$
\mathrm{N}=(\mathrm{A} \times \mathrm{X}) /(\mathrm{P} \times \mathrm{V})
$$

Em que:

$\mathrm{N}$ = número de ovos por litro da amostra;

$A$ = número de ovos contados nas três câmaras;

$\mathrm{X}=$ volume final (após a adição da solução de $\mathrm{ZnSO}_{4}$ $7 \mathrm{H}_{2} \mathrm{O}$ a $33 \%$ );

$\mathrm{P}=$ volume da câmara McMaster $0.9 \mathrm{ml}(0.3 \mathrm{ml} /$ câmara);

\section{$\mathrm{V}=$ volume original da amostra em litros}

Empregou-se ainda, a técnica de Yanko (1987, apud sOCCOL et al., 1998).

No cálculo da concentração de ovos (ovos/litro de água) neste último processo, efetuou-se uma regra de três simples. Sobre o valor encontrado não foi aplicada a taxa de recuperação dos métodos, como proposto por Coelho e Campos (1995), devido às alterações no tamanho das amostras originais, para as quais foram estabelecidas.

\section{Resultados e Discussão}

Os valores de $\mathrm{pH}$ (Figura 1), aferidos em ambas as águas, concentraram-se na faixa de $\mathrm{pH}$ neutro, e levemente básico com variação de 7,4 a 8,3 na água de abastecimento e de 6,7 a 7,7 na água residuária. Sabese que, durante o processo de decomposição da matéria orgânica, o oxigênio é consumido e o gás carbônico é liberado, formando o ácido carbônico e ocorrendo a acidificação do meio. Intensos processos de decomposição têm como conseqüência a liberação de $\mathrm{CO}_{2}$ e, portanto, a formação de ácido carbônico e hidrogênio (MATHEUS, 1993).

Nota-se que a diferença entre as concentrações de $\mathrm{pH}$ da água de abastecimento e residuária foi muito pequena, podendo-se dizer que, para este parâmetro, as águas apresentaram o mesmo padrão de qualidade.

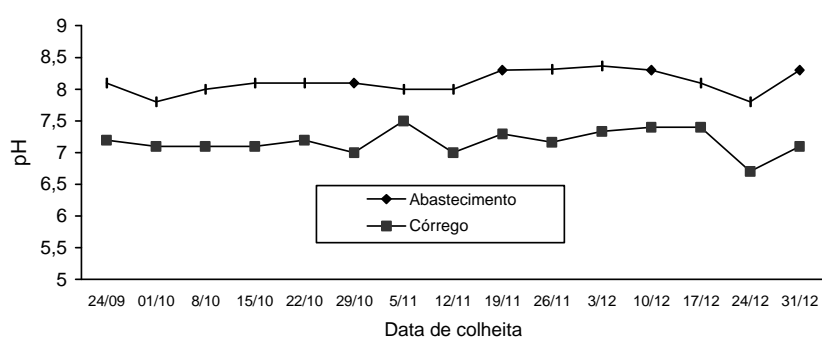

Figura 1 - Valores de $\mathrm{pH}$, de amostras de águas de abastecimento e residuária, amostradas semanalmente. FCAV/UNESP.

A variação da concentração de Oxigênio Dissolvido (OD) na água de abastecimento foi de 6,2 a 8,9 mg de $\mathrm{OD} / \mathrm{L}$ de água (Figura 2). Estes valores demonstram que esta água apresenta-se apta para os mais diversos usos, inclusive o consumo humano, e que a matéria orgânica está ausente ou em reduzida quantidade.

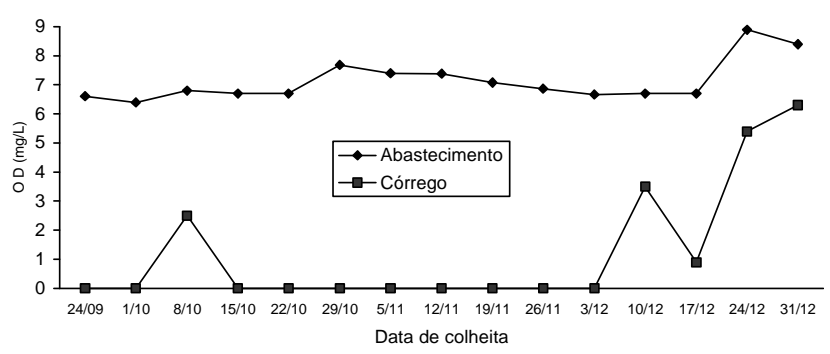

Figura 2 - Concentrações de oxigênio dissolvido (OD) de amostras de águas de abastecimento e residuária, amostradas semanalmente. FCAV/UNESP.

Na água residuária, porém, as concentrações de OD variaram de 0,0 a 6,3 mg/L e a grande freqüência de concentrações nulas indicam o alto grau de poluição, na forma de matéria orgânica, o que, pelos valores mensurados, determina uma baixa qualidade dessas águas. Problemas ambientais em corpos d'água são freqüentes devido ao excesso de matéria orgânica que consome muito oxigênio durante a decomposição. Resíduos orgânicos e inorgânicos reduzidos exercem uma demanda de oxigênio (BOYD, 1990).

A incidência e quantidade de chuvas influenciaram nas concentrações de OD; a partir de 10/12/98 (quarta semana), verificou-se o início de um período chuvoso que se estendeu até o final das amostragens. Neste período observaram-se as maiores concentrações de OD em ambas as águas, principalmente na residuária.

As principais fontes de poluição difusa são: agricultura, silvicultura, atmosfera, escoamento urbano e suburbano e águas subterrâneas; suas características são origens e descargas de águas residuais difusas. A qualidade dessas águas tende a variar com o tempo, influenciadas pelas chuvas, por exemplo (AALDERINK e LIJKLEMA, 1998).

Apesar da matéria orgânica estar presente em grande quantidade na água residuária, com concentra-ções de OD baixas e/ou nulas, o pH não apresentou concentrações reduzidas, não se observando, desta forma, a relação pH/oxigênio dissolvido. 
A relação OD/temperatura não foi observada, mas, no início do experimento (época das secas com baixas temperaturas), as concentrações de OD não foram as mais elevadas. Na fase final, época das águas com elevadas temperaturas, as concentrações foram máximas. Este é mais um indício da estreita relação observada entre os valores de OD e a incidência de chuvas.

As concentrações de nitrato apresentaram-se com valores muito baixos, variando de 0,0 a $0,51 \mathrm{mg} / \mathrm{L}$ na água de abastecimento e de 0,0 a 0,57 $\mathrm{mg} / \mathrm{L}$ na água residuária (Figura 3 ). De acordo com pesquisas realizadas por Walker et al. (1997), águas de abastecimento na cidade de Decatur e vila de Georgetown, Illinois, EUA, apresentaram concentrações de nitrato que, sazonalmente, excederam o padrão de $10 \mathrm{mg} / \mathrm{L}$. Nota-se que no período de 20/10/98 a 10/12/98 a água residuária apresentou concentrações de nitrato mais altas, as quais não eram esperadas, pois como o OD no mesmo período foi baixo, deveria ter ocorrido o processo de desnitrificação. Na maioria das colheitas, altas concentrações de OD não estiveram relacionadas a altos valores de nitrato.

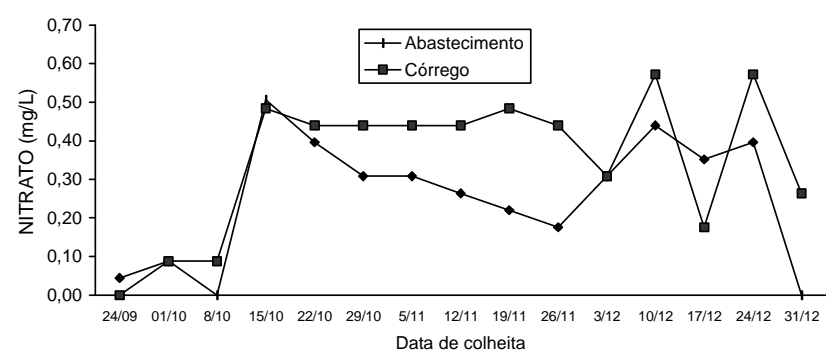

Figura 3 - Concentrações de nitrato de amostras de águas de abastecimento e residuária, amostradas semanalmente. FCAV/ UNESP.

O nitrito (Figura 4) apresentou-se em concentrações reduzidas, sendo que somente em dois momentos sua concentração pôde ser considerada indesejável para o consumo humano, na primeira e última amostragem para água residuária $(0,12$ e $0,1 \mathrm{mg} / \mathrm{L}$, respectivamente). $\mathrm{Na}$ água de abastecimento as concentrações de nitrito foram menores, variando de 0,0 a $0,02 \mathrm{mg} / \mathrm{L}$. O fato da água residuária ter apresentado concentrações de nitrito e sempre mais elevadas do que a de abastecimento, com variação de 0,02 a $0,12 \mathrm{mg} / \mathrm{L}$, pode estar a relacionado ao OD, pois baixas concentrações de OD propiciam a redução de nitrato a nitrito e, principalmente, as maiores concentrações de matéria orgânica nessas águas, evidenciadas pelas elevadas concentrações de nitrogênio amoniacal (Tabela 1).

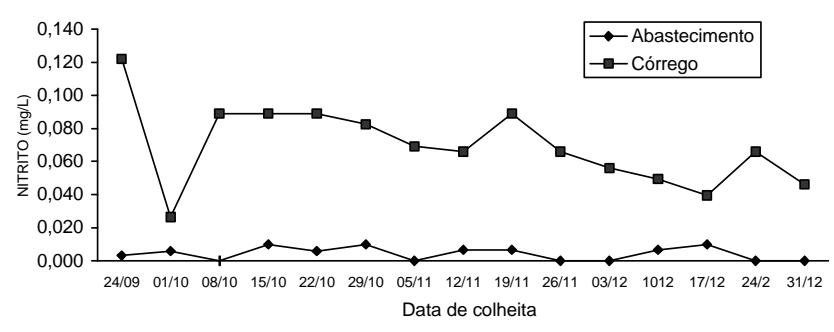

Figura 4 - Concentrações de nitrito de amostras de águas de abastecimento e residuária, amostradas semanalmente. FCAV/ UNESP.

Quanto à amônia (Tabela 1), somente em uma colheita (01/10/98) da água de abastecimento a concentração pode ser considerada preocupante $(0,7$ $\mathrm{mg} / \mathrm{L})$ para os níveis de qualidade exigidos. Nas demais datas, os valores mantiveram-se satisfatórios $(0,0$ a 0,3 $\mathrm{mg} / \mathrm{L}$ ), predominando ausência de amônia em grande parte das amostras. Por outro lado, na água residuária a concentração foi muito elevada, com valores máximos de 9,15 a $13,4 \mathrm{mg} / \mathrm{L}$; somente em dois momentos a concentração apresentou-se nula (10/12/98 e 24/12/98).

As altas concentrações de amônia estão relacionadas às baixas concentrações de OD verificadas na água residuária, pois o processo de desnitrificação torna-se acelerado, ao mesmo tempo que indica fontes de poluição próxima ou recente (BATALHA e PARLATORE, 1993). Observa-se que as maiores concentrações de amônia ocorreram quando os valores de OD eram nulos

Tabela 1 - Valores das concentrações de amônia ( $\mathrm{mg} / \mathrm{L})$, de amostras de águas de abastecimento e residuária, amostradas semanalmente.

\begin{tabular}{|c|c|c|c|c|c|}
\hline \multirow{2}{*}{$\begin{array}{l}\text { Amostragens } \\
\text { (Dias) }\end{array}$} & \multicolumn{2}{|c|}{ Amônia (mg/L) } & \multirow{2}{*}{$\begin{array}{l}\text { Amostragens } \\
\text { (Dias) }\end{array}$} & \multicolumn{2}{|c|}{ Amônia (mg/L) } \\
\hline & Abastecimento & Córrego & & Abastecimento & Córrego \\
\hline $24 / 09$ & 0,4 & 6,0 & 03/12 & 0,0 & 6,7 \\
\hline $01 / 10$ & 0,7 & 5,0 & $10 / 12$ & 0,0 & 0,0 \\
\hline $08 / 10$ & 0,0 & 0,9 & $17 / 12$ & 0,0 & 3,4 \\
\hline $15 / 10$ & 0,3 & 9,1 & $24 / 12$ & 0,0 & 0,0 \\
\hline $22 / 10$ & 0,0 & 9,1 & $31 / 12$ & 0,0 & 5,0 \\
\hline $29 / 10$ & 0,0 & 6,4 & 07/01 & 0,2 & 11,9 \\
\hline $05 / 11$ & 0,0 & 13,4 & $14 / 01$ & 0,0 & 3,0 \\
\hline $12 / 11$ & 0,0 & 9,8 & $21 / 01$ & 0,0 & 3,9 \\
\hline $19 / 11$ & 0,0 & 11,3 & $28 / 01$ & 0,0 & 0,9 \\
\hline $26 / 11$ & 0,0 & 9,1 & ---- & ---- & ---- \\
\hline
\end{tabular}


e, conseqüentemente, quando o OD esteve presente, o nível de amônia apresentou uma redução.

Altas concentrações do íon amônio podem ter grandes implicações ecológicas como, por exemplo, influenciar fortemente a dinâmica de oxigênio do meio, uma vez que para oxidar 1,0 miligrama desse elemento, são necessários cerca de 4,3 miligramas de oxigênio; podem também influenciar a população de peixes, pois em pH básico o íon amônio se transforma em amônia que, dependendo de sua concentração, pode ser tóxica (BOYD, 1990).

Na Tabela 2 são apresentados os valores de demanda química de oxigênio (DQO) e demanda bioquímica de oxigênio (DBO). A DQO da água de abastecimento apresentou-se com valores baixos durante todo período de colheita, com valor máximo de $18 \mathrm{mg} / \mathrm{L}$ e mínimo de $0,0 \mathrm{mg} / \mathrm{L}$. Esses dados estão de acordo com as altas concentrações de OD encontradas nessas águas, pois a demanda por oxigênio foi reduzida.

Em contrapartida, na água residuária, as concentrações de DQO foram elevadas, principalmente na primeira metade das colheitas, com variação de 32 a $201 \mathrm{mg} / \mathrm{L}$. Também se verificou a relação da $\mathrm{DQO}$ com o OD, pois, como nas primeiras amostras, o oxigênio manteve-se praticamente nulo e os valores de DQO foram altos. Nas amostras finais, com o aumento da concentração de OD, ocorreu uma redução nas concentrações de DQO. Nota-se que os maiores valores de DQO foram encontrados nas menores concentrações de OD, sendo que o inverso não ocorreu, ou seja, nas maiores concentrações de OD os valores de DQO não foram os mais baixos.

Os valores de DBO (Tabela 2) foram nulos para todas as colheitas de água de abastecimento, estando de acordo com as concentrações de OD e DQO aferidas. $\mathrm{Na}$ água residuária, a DBO esteve presente em todas as colheitas, variando de 18 a $113 \mathrm{mg} / \mathrm{L}$. Observou-se a estreita relação da DBO com O OD e DQO, pois as maiores concentrações desses parâmetros equivalem aos maiores valores de DBO. Nota-se ainda que no período final das colheitas, quando o OD e DQO tiveram suas concentrações reduzidas, o mesmo aconteceu com a DBO. Os valores de DBO da água residuária indicam a presença de matéria orgânica, a qual proporciona uma demanda por oxigênio.

\subsection{Avaliação microbiológica (coliformes totais e coliformes fecais) das fontes de água}

Pelos resultados da avaliação microbiológica das amostras de água (Tabela 3) observa-se que na água de abastecimento, mesmo sem receber qualquer tipo de tratamento, 64,7\% das amostras apresentaram valores de coliformes totais e fecais dentro dos padrões da Portaria n-1469, de 20 de dezembro de 2000

Tabela 2 - Valores das concentrações de DQO e DBO (mg/L), de amostras de águas de abastecimento e residuária, amostradas semanalmente FCAVJ/UNESP.

\begin{tabular}{ccccc}
\hline \multirow{2}{*}{$\begin{array}{c}\text { Amostragens } \\
\text { (Dias) }\end{array}$} & \multicolumn{2}{c}{ DQO (mg/L) } & \multicolumn{2}{c}{ DBO (mg/L) } \\
\cline { 2 - 5 } $24 / 09$ & 0,0 & 198 & 0,0 & Abastecimento \\
$01 / 10$ & 2,0 & 201 & 0,0 & Residuária \\
$08 / 10$ & 18 & 135 & 0,0 & 104 \\
$15 / 10$ & 0,0 & 169 & 0,0 & 18 \\
$22 / 10$ & 0,0 & 179 & 0,0 & 64 \\
$29 / 10$ & 4,0 & 120 & 0,0 & 98 \\
$05 / 11$ & 3,0 & 132 & 0,0 & 76 \\
$12 / 11$ & 2,0 & 156 & 0,0 & 85 \\
$19 / 11$ & 4,0 & 161 & 0,0 & 81 \\
$26 / 11$ & 0,0 & 196 & 0,0 & 110 \\
$03 / 12$ & 3,0 & 124 & 0,0 & 113 \\
$10 / 12$ & 15 & 51 & 0,0 & 72 \\
$17 / 12$ & 1,5 & 85 & 0,0 & 33 \\
$24 / 12$ & 7,0 & 57 & 0,0 & 41 \\
$31 / 12$ & 12 & 102 & 0,0 & 53 \\
$07 / 01$ & 0,0 & 32 & 0,0 & 43 \\
$14 / 01$ & 0,0 & 48 & 0,0 & 26 \\
$21 / 01$ & 0,0 & 52 & 0,0 & 31 \\
$28 / 01$ & 0,0 & 54 & 0,0 & 38 \\
& & & & 22 \\
\hline
\end{tabular}


Tabela 3 - Número médio de coliformes totais e fecais por $100 \mathrm{~mL}$ e \% de amostras positivas e negativas de água de abastecimento e residuária amostradas semanalmente entre 24/09/98 e 28/01/99, num total de 19 amostragens.

\begin{tabular}{|c|c|c|c|c|c|c|c|}
\hline \multirow{2}{*}{$\begin{array}{l}\text { Fontes } \\
\text { de } \\
\text { Água }\end{array}$} & \multicolumn{3}{|c|}{ Coliformes totais } & \multicolumn{3}{|c|}{ Coliformes fecais } & \multirow{2}{*}{$\begin{array}{c}\text { Amostras } \\
\text { positivas } \\
(\%)^{2}\end{array}$} \\
\hline & N.ำ Médio & Ampl. Var. ${ }^{1}$ & $\begin{array}{c}\text { NMP } \\
>2 / 100 \mathrm{~mL} \\
(\%)^{2} \\
\end{array}$ & N.ํMédio & Ampl. Var ${ }^{1}$ & $\begin{array}{c}\text { NMP } \\
>2 / 100 \mathrm{~mL} \\
(\%)^{2} \\
\end{array}$ & \\
\hline Residuária & $4275 \times 10^{5}$ & $\begin{array}{c}7,5 \times 10^{6} \mathrm{a}^{1,5 \times 10^{9}}\end{array}$ & 100,0 & $\begin{array}{c}1,1 \times 10^{6} a \\
2,3 \times 10^{8}\end{array}$ & $4,12 \times 10^{7}$ & 100,0 & 100 \\
\hline Abastecimento & 39,12 & $<2$ a 170 & 70,6 & $<2$ a 23 & 9,4 & 23,5 & 35,3 \\
\hline
\end{tabular}

${ }^{1}$ Amplitude de variação

2 Amostras com NMP $>10$ para coliforme total ou NMP $>2$ para coliforme fecal $/ 100 \mathrm{~mL}$.

(BRASIL, 2001). Os resultados positivos para coliformes $(35,3 \%)$ indicam que há necessidade de se realizar maior controle sobre a qualidade da água distribuída no Campus, uma vez que a contaminação pode estar ocorrendo nos reservatórios e ou nos condutos de distribuição.

A predominância de amostras positivas para coliforme total justifica-se por esta categoria reunir um grande número de bactérias tanto do trato digestivo dos mamíferos quanto bactérias do solo, igualmente identificadas pelas mesmas técnicas laboratoriais presuntivas. No entanto, a presença de coliformes fecais, indica a contaminação por fezes.

Para amostras de água do córrego Cerradinho (Tabela 3), 100\% encontravam-se acima dos limiares estabele-cidos pela Resolução no 20 do Conselho Nacional do Meio Ambiente - CONAMA (BRASIL, 1986) que estabe-lece o valor máximo permitido de 4000 coliformes/100 mL, para a Classe 3. Portanto, não é indicada a sua utili-zação para a irrigação de hortaliças, plantas frutíferas, culturas arbóreas, cerealíferas e nem para forrageiras.

As águas contaminadas por fezes são potencialmente veiculadoras de Salmonella, constituindo-se em perigo para a manutenção da saúde, quando servida como água de dessedentação, ou mesmo como água de higienização. Segundo Ruiz (1992), as Salmonella spp. são particularmente "hídricas" (sobretudo $S$. typhimurium,), podendo sobreviver por mais de 100 dias nos reservatórios de água e multiplicar-se, principalmente se esta for rica em material orgânico.

Os resultados verificados confirmaram a periculosidade em permitir o acesso humano e animal a água proveniente de córregos que recebem esgoto urbano e ou rural, sem qualquer tratamento.

Em um plano de fiscalização de hortas em Ribeirão Preto - SP, parte de um programa estratégico para o controle do complexo teníase/cisticercose, Takayanagui, (1998) verificou que de 196 hortas fiscalizadas, através de exames microbiológicos das verduras, vinte e duas apresentaram alta concentração de coliformes fecais e outras quatro estavam contaminadas com Salmonella.
Exames parasitológicos nas hortaliças revelaram contaminação por vários enteroparasitos patogênicos ao homem, como Ascaris sp., Giardia sp., Strongyloides sp. e Hymenolepis nana. Duas dessas "hortas" foram flagradas utilizando água de córregos, sabidamente poluídos, na irrigação das plantas cultivadas.

\subsection{Avaliação Qualitativa e Quantitativa dos Ovos de Helmintos nas Águas do Córrego Cerradinho}

$\mathrm{Na}$ Tabela 4 são apresentados os resultados das análises parasitológicas da água poluída por esgotos, tomando-se como valor médio aquele referente ao método que proporcionou maior contagem de ovos e maior número de amostras positivas para cada gênero de helminto.

Verificou-se que a concentração de ovos de helmintos era elevada na água do córrego Cerradinho, principalmente por ovos de helmintos parasitos de humanos ou de suínos $(500,560,200,60,70$ e 50 ovos de Ascaris $s p$. ., Trichuris sp., Capillaria, Hymenolepis, Taenia sp. e Estrongilideos, por litro, respectivamente). A presença de ovos de tênias indicou que estas águas possivelmente contribuem para a manutenção do complexo teníase/cisticercose quer seja em bovinos ou suínos.

Coelho e Campos (1996), analisando amostras de esgoto bruto da cidade de Inhumas, Goiás, colhidas em estação de tratamento de esgotos domésticos, verificaram a ocorrência de concentrações de 2910 ovos por litro para Ascaris sp., 142 ovos para Trichuris trichiura, 261 ovos de Taenia sp. por litro, concordando com os achados do presente trabalho, em que se verificou a predominância de ovos de Ascaris em relação aos demais helmintos.

Os resultados bacteriológicos e parasitológicos da água residuária indicam claramente a necessidade de tratamento dos despejos orgânicos realizados neste córrego, uma vez que é tido como fonte de água tanto para a dessedentaçao animal e para a rega de olerícolas estabelecidas às suas margens. 
Tabela 4 - Número médio de ovos de helmintos por litro de água residuária, amostrada semanalmente entre 24/ $09 / 98$ e 26/01/99.

\begin{tabular}{lccc}
\hline $\begin{array}{c}\text { Gêneros } \\
\text { De } \\
\text { Helmintos }\end{array}$ & Média & Omplitude de variação & Amostras positivas (\%) \\
\cline { 2 - 4 } Ascaris & 272,30 & 0 a 500 & 92,31 \\
Trichuris & 76,92 & 0 a 560 & 84,62 \\
Capillaria & 23,85 & 0 a 200 & 38,46 \\
Hymenolepis & 15,38 & 0 a 60 & 53,85 \\
Taenia & 18,46 & 0 a 70 & 53,85 \\
"Estrongilídeos" & 4,6 & 0 a 50 & 15,38 \\
\hline
\end{tabular}

\section{Conclusões}

A água denominada de abastecimento e servida à comunidade universitária da UNESP Campus de Jaboticabal necessita de maior controle higiênico sanitário, a fim de se detectarem os possíveis pontos de contaminação e solucionar o problema de inconstância na qualidade apresentada.

A água residuária apresenta características que demandam processo de tratamento antes de sua utilização, principalmente em relação à elevada concentração de patógenos, às concentrações de amônia e matéria orgânica.

Pesquisas futuras nestas águas devem ser incentivadas, ampliando-se o número de parâmetros analisados e abrangendo características físicas e biológicas.

\section{Referências Bibliográficas}

AALDERINK, H.; LIJKLEMA, L. Water quality modeling. In: CURSO Internacional De Modelação E Monitoramento De Ecossistemas Aquáticos: resumos. Bogotá: Universidad de Bogota, 1998. 14p.

ALABURDA, J.; NISHIHARA, L. Presença de compostos de nitrogênio em águas de poços. Rev. Saúde Pública, São Paulo, v.32, n.2, p.531-537, 1998.

AMERICAN PUBLIC HEALTH ASSOCIATION. Standard methods for the examination of water and wastewater. 17.ed. Washington, 1992. 619p.

ARCHIBALD, E.M. Watershed sanitary survey of the California State Water Project. Water Suplly, vol.12, n.1-2, p.9-12, 1994.

AYRES, R.M.; MARA, D.D. Analysis of wastewater for use in agriculture: a laboratory manual of parasitological and bacteriological techniques. Geneva: World Health Organization, 1996. 31p.

BATALHA, B.H.L.; PARLATORE, A.C. Controle da qualidade da água para consumo humano: bases conceituais e operacionais. São Paulo: CETESB, 1993.

BOYD, C.E. Water quality in ponds for aquaculture. Alabama: Birmingham, 1990. 482p.
BRASIL. Ministério da Saúde. Portaria no 1469, de 20 de dezembro de 2000. Estabelece os procedimentos e responsabilidades relativas ao controle e vigilância da qualidade da água para consumo humano e seu padrão de potabilidade. Diário Oficial [da] Republica Federativa do Brasil, Brasília, DF, 02 jan. 2001.

BRASIL. Ministério do Meio Ambiente. Conselho Nacional do Meio Ambiente. Resolução $n^{\circ} 20$. de 18 de junho de 1986. Estabelece a classificação das águas, doces, salobas e salinas do Território Nacional. Diário Oficial [da] Republica Federativa do Brasil, Brasília, DF, 30 jul. 1986. p1-23. Disponível em: <http://www.mma.gov.br/port/ CONAMA/res/resol86/res2086.htm>.

COELHO, M.W.; CAMPOS, D.M.B. Avaliação da eficiência de um sistema de lagoas de estabilização na remoção de ovos de helmintos: proposta para a determinação do percentual de recuperação de ovos de helmintos através do método de Schwartzbrod. Rev. Patol. Trop.,Goiania, v.25, n.1, p.61-72, 1995.

GOLTERMAN, H.L., CLYMO, R.S., OHNSTAD, M.A.M. Methods for physical and chemical analysis of freshwaters. London: Blackwell Scienc. Publishing, 1978. 214p. (IBP Handbook, 8).

HIGASKINO, C.E.K. et al. Determinação de coliformes fecais em amostras de lodo de esgoto por fermentação em tubos múltiplos In: ANDREOLI, C.V., BONNET, B.R. Manual de métodos para análises microbioló-gicas e parasitológicas em reciclagem agrícola de lodo de esgoto. Curitiba: Sanepar, 1998. p.27-35.

MATHEUS, C. E. Policultivo de peixes em efluentes de indústrias de processamento de frutas cítricas e efeitos na qualidade da água. 1993. 375f. Tese (Doutorado) Departamento de Hidraúlica e Saneamento, Escola de Engenharia de São Carlos, Universidade de São Paulo, São Carlos, 1993.

RENEW AMERICA. "Drinking Water": the state of the States 1989. Washington, DC, 1989 p.18-23.

RUIZ, R.L., Microbiologia do ar e da água zootécnica. In: p.50. . Microbiologia zootécnica. São Paulo: Roca, 1992.

SÃO PAULO(Estado). Secretária do Meio Ambiente. Legislação estadual: controle de poluição ambiental do Estado de São Paulo. São Paulo: 1990. 203p. 
SOCCOL, V.T.; PAULINO, R.C.; CASTRO, E.A. Metodologia de análise parasitológica em lodo de esgoto e esgoto. In: ANDREOLI, C.V., BONNET, B.R. Manual de métodos para análises microbiológicas e parasitológicas em reciclagem agrícola de lodo de esgoto. Curitiba: Sanepar, 1998. p.2735.

SOUZA, R.M.G.L.; PERRONE, M.A. Padrões de potabilidade da água. 12p. Disponível em: <http.cvs.sal.sp.gov.brpvol2. html>. Acesso em : 10 jan. 2000.

TAKAYANAGUI, O.M. Complexo teníase/cisticercose. Rev. Cons. Fed. Med. Vet., v.4 n.14, p.9-12, 1998.

WALKER, S.E., MITCHELL, J.K., HIRSCHI, M.C., et al. Nitrate in agricultural watersheds: a comparison of two tile-drained watersheds in East-Central Illinois. Transactions of the ASAE, n.972154, 1997.

WORLD RESOURCE INSTITUTE AND INTERNATIONAL INSTITUTE FOR ENVIRONMENT AND DEVELOPMENT. World Resources 1988-89. New York: Basic Books, 1988. p.128. 